\title{
CHALLENGING GENDER EQUALITY IN SOUTH AFRICAN TRANSFORMATION POLICIES - A CASE OF THE WHITE PAPER: A PROGRAMME FOR THE TRANSFORMATION OF HIGHER EDUCATION
}

\author{
B. M. Akala \\ Department of Teaching and Learning \\ University of Johannesburg \\ Johannesburg, South Africa \\ e-mail: akalabetty@yahoo.com
}

\section{ABSTRACT}

Using a post-structural lens, I make arguments against homogenising people's conditions and circumstances. In particular, I acknowledge that the post-1994 reform agenda intended to streamline the previously fragmented and segregated higher education landscape under the apartheid regime. Black women, who are the main target of this article suffered triple marginalisation - race, social class and sexism. The aim of the article is to show the tensions that exist within the White Paper: A Programme for the Transformation of Higher Education (DoE 1997). The said tensions have stifled the attainment of gender equity and equality; effectively widening the gender fissures in post-1994 South African higher education. I argue that we should not take for granted phrases such as "equal opportunities" and "equal access" in policies. Instead, we should seek their meaning and achievement inter alia in earnest for the targeted group. Therefore, I postulate that gender and gendering is complex and very fragmented. For this reason, formulating transformation interventions on the premise of equality for all does not necessarily guarantee gender equality or gender equity. With this in mind, a "one-size fits all" approach to redressing gender equality is implausible and does not suffice in addressing salient gender injustices. I propose a multifaceted approach, which encompasses a realistic and holistic outlook on the divergent needs of black women in particular and women in general as a possible solution to the current challenges.

Keywords: gender, equity, equality, policy, higher education

\section{INTRODUCTION}

How well has post-1994 South African higher education performed in meeting its transformation targets, especially regarding gender equality? Answers to this question are deeper than the data and literature that shows that women have fared well post 1994. Coetzee (2001) argues that the post-1994 legislation has not achieved the aim of equalising gender in 
society in general, and education in particular. Coetzee further contends that, despite overcoming some gender inequalities, largely, education institutions bear the blame of embedding gender discrimination in their structures.

Despite overwhelming evidence indicating, women representation has surpassed that of men, gender gaps are still evident. Women's participation and representation is at 57 per cent whereas men's participation and representation is at 43 per cent. However, the promising figures herewith ought to be the starting point of interrogating the reality of gender and gendering in higher education. The absence of a counter narrative will promote a misconceived grand narrative of gender, gendering and gender differentiation in South African higher education that will obfuscate transformation goals (Akala 2016; CHE 2013; CHE 2009; Badat 2009; Draft Green Paper, DET 2012).

Abstractions from emerging literature indicate that very few women are pursuing Science Technology Engineering and Mathematics (STEM) science-related courses (CHE 2013). Data from CHE (2013) indicates that most women are concentrated in humanities, social sciences, education, economics and management sciences as well as the arts. Similar data shows that very few women enrol in engineering, built environment and science-related courses. Nationally, data from 2007 demonstrate that men dominate engineering, science and technology (57\%), women dominate other fields: business, commerce and management (56\%), education (73\%), and human and social science (59\%). I note that this trend has been consistent since 2004 (CHE 2013).

Closely related to the above; sexism, economic circumstances, social class and cultural factors perpetuate gender inequalities. This is true especially black women not succeeding in post-1994 higher education (Hassim 1991). Against this backdrop, I argue that, largely, realising gender equity and equality is complex and problematic. I have adapted Rawls’ (2009) conceptualisation of equality (first principle - premised on equal people, enjoying equal liberties and opportunities (horizontal)) and equity (second principle - based on the well-being of individuals perceived to be unequal (vertical). Women have a lot in common, however, the differences they embody weigh more heavily in gender-related interventions; which, in my view necessitates the embracing of the equity paradigm. In fact, the White Paper (DoE 1997) envisages and presupposes a higher education landscape that is devoid of any forms of discrimination.

Using secondary data and philosophical arguments, I aim to offer clarity on the assumption that gender equity and equality has been achieved post 1994. I contest the aggregated data that suggests that women, and not men, have benefitted greatly from the reform 
agenda. I conclude that, instead of relying on aggregated data, a more concise analysis of particular areas of marginalisation will give policy makers and practitioners a good indication of the areas that require reviewing and recalibration.

Do contexts and individual experiences count in redress projects and policies? Mills explicates that there is a nexus between individual experiences and social institutions (Mills 2003). On the other hand, Ball (2006) argues that policies have to take into cognisance policy contexts, which play a crucial role in the inception and implementation stages. With this is mind, I argue that a robust and equitable higher education depends on how well the structures are prepared to implement the policies they receive, how the policies articulate the needs of those they are meant to protect and cushion and, how far the people within the structures have transformed or are prepared to transform. Take the case of the majority of blacks who had little access to higher education opportunities during the apartheid regime; their experiences of higher education would not be amorous if the current structures have not changed substantially. They would continue to experience racism and rejection in institutions that should be otherwise free and inclusive for all.

We cannot dispute the fact that gender segregation was a big part of the apartheid policies. Black students were victims of exclusion due to race, gender, social class and ethnicity (male and female). Nevertheless, an overlap in these factors meant that black women suffered the most. It is because of this reason that I have taken a keen interest in looking at gender in relation to black women accessing education. Considering the gaps within the previous system, the White Paper (DoE 1997) is one of the most important policy documents that heralded transformation post 1994. Through its objectives, the creation of a unitary system became a reality. The White Paper also indicates the various categories of equity. However, 20 years into independence, higher education is still grappling with gender inequity and disparities. Blaming the conundrum on appropriating less attention to gender equity vis-a-viz race and social class equities is not far-fetched. I note that, although the policy promotes inclusivity; black women still face more nuanced alienations in terms of social class, race, epistemological access, language and sexual abuse and harassment.

While iterating the equity paradigm, I agree with the Commission on Gender Equality (CGE 2000) that argues that women experienced decades of marginalisation differently - even within groups that seemed to be homogenous. The divergences are attributable to ideological and hegemonic positions that were, and, remain, vehicles of differentiation (CGE 2000; Hassim 1991). Arguably, although women faced injustices in general during the colonial and apartheid eras, black women in particular suffered what has been termed "triple marginalisation”, that of 
race, social class, and sex.

The structure of the article is as follows; the first section introduces the article; the second section discusses various aspects of gender and gendering, the third section looks at the paradox of history, race, gender, and agency. The fourth section explores the effect of patriarchy in the creation of gender inequalities; section five delves into the trajectory and context of past trends of gender inequalities in South African higher education and the fifth section explores the link between post-structuralism and the gendering in policies. The final section provides a summary of the discussions in the article.

\section{VARIOUS DIMENSIONS OF GENDER, GENDERING AND REDRESS POLICIES}

The new dawn was very promising for the black woman of South Africa, the inception of promising gender regulations and policy frameworks promised justice and fairness to all. Judging by the current postings in higher education - achievements and areas of further disadvantage, we can applaud several positive milestones achieved this far. Currently more women are accessing education as compared to the apartheid era (CHE 2013; CHE 2010; DET 2012). Emerging literature has indicated that the enacted policies have brought about meaningful change in institutions of higher learning. Seemingly, equity in terms of student demographics appears to be on course. Substantive changes have occurred in the representation of black students, and in particular, black women in higher education (Akala and Divala 2016; Jansen 2003; CHE 2009; Badat 2009; 2010; DET 2012). The above nuances seem to make a strong case for success and achievement of transformation policies.

However, what is under contention is the idea that numbers do not tell the whole story about people's experiences in social institutions. The next level of engagement with current literature shows that although the change in demographics is evident and laudable, it is also evident that higher education is grappling with many challenges, of which gender equity is one (Badat 2009; CHE 2010). This has led some to conclude that, in spite of the promise of equity and equality of access and participation in higher education policies, gender equity remains as elusive now as during previous regimes (Unterhalter 2007; Chisholm and September 2005). While supporting this claim, I note that higher education policies and the strategies that are in place have not taken a keen interest in the particular circumstances that individual black women who go to institutions of higher learning, face on a daily basis. Thus, homogenising women perpetuates injustices instead of dealing with them decisively (Meintjies 1996; Martineau 1997). Young (1990); Mackinnon (1993) and Fraser (2005) share the aforementioned assertion. Notwithstanding the above, a majority of the redress policies that were enacted post-1994 give 
a lot of attention to equity in terms of race-related forms of marginalisation as compared to gender equity (Martineau 1997). The implication of this approach is that specific and particular black women's issues have lacked depth and breadth in the transformation agenda. They have either been submerged in other discourses such as race and social class or been ignored all together. In this regard, Martineau (1997) and Hassim and Walker (1993) postulate that many scholars have been silent about black women's experiences in education. The silence, according to Young (1990) and Fraser (2005) promotes misinterpretations, misrepresentations and misrecognition of the particular and specific experiences of a disenfranchised group.

\section{THE PARADOX OF HISTORY, RACE, GENDER AND AGENCY}

Apart from the marginalisation of black people in general, black South African women's suffering originates from a variety of nuanced factors, otherwise known as a triple tragedy, caused by racism, social class and sexism (Hassim 1991). Race uses colour as a major factor to extol superiority and privilege on the one group, and inferiority and subservience on the other. Racism on the other hand is an ideology that justifies the dominance of one race group over other races. According to Lorde $(1984,110)$, racism is "the belief in the inherent superiority of one race over all others and thereby the right to dominance”. In the case of South Africa, there is a clear link between race and racism, and colonialism and apartheid. In which case, the misconstruing of white peoples' dominance and privilege (social, economic and political) over black people as (being inherent) was a mechanism to distort and misrepresent facts for their own benefit (dominant and political class).

The manifestation of sex and sexism uses the same prism-masculinity being inherently superior to femininity. Such unfounded allocations find support in skewed arguments advanced by innatists who view women as weaker beings in comparison to men based on biological factors. Sexism advances and promotes biasness, stereotyping and prejudicial positions against women (Tiger and Fox 1972; Murdock 1949; Parsons 1954). As for South Africa, stringent patriarchal systems cut across racial and cultural divides (CGE 2000).

The intermittent gender relations in South Africa are replete with contradictions formed around a dialectical relationship. That, on one hand sees human action in the form of women engagement in the liberation struggle, and structural constraints around racism, and on the other hand, the dominant and subordinate master/servant relationship (Comaroff 2013). Sadly, the predominant discourse during the struggle period rallied around race hegemony and not gender and sexism (Molteno 1984). Whilst gender, race and class intersect, interventions for racism and classism took precedence over gender oppression. This was due to the dominance of race 
in the political and legal ordering of South African society. At issue here is the tension within the South African women's collective liberation consciousness that divided them along racial and class lines. Middle-class white women were mainly concerned with the acquisition of political and legal rights. In contrast, black women quested for liberation and the acquisition of political and economic rights (Hassim and Walker 1993; Walker 2005). According to Walker (1990), racial segregation and subordination created new forms of racial and gender inequality amongst women.

Largely, a majority of indigenous cultures often promote patriarchy and sexism. Nevertheless, in some cases, women were not completely subdued in indigenous cultures. They enjoyed some status as producers in rural farming communities even though they did not have authority. Meintjies (1996) notes that, even under the harsh circumstances, women found a way of asserting some level of independence and autonomy out of traditional and customarily law, especially the few educated ones. From the above assertion, it is clear from Comaroff that education is important in sensitising women of their rights and enabling them to stand up against oppression and oppressors - similar views advanced by Nussbaum (Nussbaum 1999; Sen 1980). Nevertheless, with the advent of new land reform in South Africa, the scarcity of arable land that had been in the hands of the chiefs, devalued women's status as producers. The heightening of gender marginalisation occurred through draconian requirements that denied women autonomy in land-related matters. Farmland allocation depended on an attachment to a male family member. If they did not have a male kin, the chief would decide on the allocation (Walker 1990). Even then, this was very demeaning and devaluing to women in such communities. Cleary, the treatment amounted to violation of their rights and inhibited them from enjoying their full rights as citizens.

Meinjties (1996) explains that the law denied rural women adult status. This barred them from owning or inheriting land or moveable property and from accessing credit. In addition, whereas motherhood was the sole responsibility of women, guardianship and custody of children rested with men (Meintjies 1996, 53). These restrictions put women in a precarious situation, for the regime failed to guarantee their political, legal, socio-economic and reproductive powers and rights. Treating women as weak, irrational, undeserving of any rights and as always attaching them to a male figure, is entrenched in innatist views of the dominance of masculinity and inferiority of femininity (Oakley 1985; Tiger and Fox 1974).

Women's subjugation was further entrenched when the colonial authorities incorporated traditional leaders into their governing systems and introduced customary law that formally instituted the inferiority of women to men. Customary law applied to black women; western 
law governed “Indian” and “Coloured” women, whereas Muslims were under personal law (Walker 1990). Hassim (1991) argues that as far as black women suffered, in a general sense, they were not alone in this struggle, only the degree of suffering varied. She further observes that this view delineates and silences the oppression of race groups other than blacks. The historic march against the Pass Laws to the Union Building in Pretoria in 1956 was in solidarity with each other - race, religion or creed did not separate them.

Women in the 1930s saw the need to fend for themselves and their families; this saw an influx of women into the urban centres in search of opportunities. The reinforcement of restricted movement for women into cities was “legal”. Linking mining and gender promoted sexism and disadvantaged women (making it a preserve of men). Black women remained in the rural areas and worked as casual labourers on farms. Others moved to cities to work as domestics, hawk, or brew or sell beer in informal settlements (Walker 1990). Demeaning (i.e. they are despised and have low returns) as these jobs were, they provided women and their families with food and shelter. Subsequently, the new reality of the black South African woman was marred with a plethora of limitations. Women lacked protection from the law and denied meaningful access to education, housing, transportation, health services and economic opportunities due to the colour of their skin. White South African women on the other hand, had limitations economically and professionally (Comaroff 2013; Meintjies 1996; Martineau 1997). A few choices were available to them as far as jobs were concerned. They mainly occupied positions relating to traditional gender roles such as clerical and secretarial jobs. Functions such as opening an account and accessing loans required permission from their husbands. A conservatism based on the binary of superiority and inferiority of men and women respectively within the Afrikaner and English communities impacted on the positioning of white women in the economy (Meintjies 1996; Msimang 2001).

In the urban centres and rural areas, black women devised survival strategies (human action and agency) and support systems to help them deal with economic and political oppression as well as cultural dislocation. They formed manyano (women's guilds), which were attached to churches, burial societies and savings groups (stokvels). According to Hassim (1991), these survival strategies did not address the underlying political ideology or structural forces that oppressed and subjugated them. Therefore, the political inclination of some women led them to choose political engagement as a survival tactic. Through Hassim's writing, it is clear that women in the 1930s had agency, and they could organise themselves around issues that concern them. Comparing the women of 1930s and the 2000s, one can argue that there are many parallels as women continue to experience marginalisation in current democratic 
structures and yet their conditions are supposed to have improved (Unterhalter 2007; Msimang 2001).

The 1950s unravelled other forms of agency, ANC Women's League (ANCWL) and the Federation of South African Women (FSAW) organised boycotts against pass laws, education and transport in townships (Meinjties 1996). Likewise, during the 1980s, women organised themselves and took different positions in relation to issues of women in leadership, the cruelty of the administration and their day-to-day survival struggles. The strengthening of trade unions made it possible for the organisations to grow and thrive. The role of women in the liberation struggle in the 1970s and 1980s was to cement their place in the new democracy. Nevertheless, Hassim (1991) notes that opposition politics of the 1980s was concerned with mobilising women for the national liberation struggle rather than for their own liberation. Women continued to occupy the private spaces in politics whereas men were in the public sphere. Hassim (1991) further argues that such an approach reinforced male dominance rather than challenge the patriarchal order. Having demonstrated the important role women played in the struggle, many question whether women managed to secure their position in society as a result. Some have been positive about the current positioning of women by arguing that increased representation in strategic positions in Parliament and other spheres of the government is a good measure of success (De la Rey and Kottler 1999). However, to the contrary, the representation in Parliament did not do much regarding the poor living arrangements, socio-economic deprivations, inaccessible and subliminal participation in education or the poor healthcare facilities for majority of the poor, rural and semi-urban women.

Pursuant to factors that have been discussed regarding the subjudication of black people in general and women in particular, one of the key challenges in the South African transformation agenda is how to create a balance between gender, race and social class. Seidman (2003) postulates that although race has gotten primacy in transformation discourses, it has become increasingly impossible to separate race, gender and class because they intersect. They are embedded and imbricated in systems; institutional traditions and cultures practiced in institutions of higher learning. Seidman's observations (2003) support the view that gender inequality and inequities cannot be resolved adequately through the adaption of a monolithic approach. Gender is dynamic and multiple, it's not unitary, utopia and homogeneous. Therefore, approaches and strategies that are multifaceted are most likely to deal with the gender impasse (Nussbaum 2009; Unterhalter 2007) 


\section{PATRIARCHY AND THE CREATION OF GENDER INEQUALITIES}

Besides factors related to race and social class, literature also shows that patriarchy has been at the centre of propagating gender inequalities in the past and in contemporary times. This is to say that, patriarchy has long been associated with many of the woes that have been experienced by women in general and black women in particular (CGE 2000). The ANC Gender Policy Discussion Paper (2000) describes patriarchy as a system of ideologies, values, beliefs and practices that differentiates and propagates unequal relations between men and women. Having noted the above, patriarchy has subordinated women in all spheres of life, whether private or public spaces. Social institutions and cultural practices reassert and reproduce male dominance and female inferiority. They allocate women roles and positions that are explicitly and predominantly feminine and inferior (Butler 1990). Mostly, they occupy invisible positions, as they are not part of significant decision-making mechanisms. In view of the above, Butler (1990) argues that patriarchy influences gender relations and determination of privileges and disadvantages in determined social spaces.

Some have opined that in medieval time in western communities, patriarchy was a noble duty. Men prided themselves in taking headship and protection roles in their families. Husbands cared for, and provided for their wives the immediate milieu. Nevertheless, there defining of relationships meant that men got more power and status whilst women became inferior. The normalisation of relationships happened and extended to the regulation of all in society. The shift and destabilisation led to greater inferiority and subordination of women and "supremacy of the fathers” (Coetzee 2001). Ideally, in biblical times, women were not inferior to men, but they had loving and complementary relationships of guidance and support (Coetzee 2001). Again, this is debatable because the "guidance and support relation" is open to various interpretations.

The definition of patriarchy as provided by the CGE (1998) puts into perspective gender injustices. The CGE $(1998,1)$ states that patriarchy buttressed domination of men over women: “... as the common denominator of the South African nation; it is a system of domination of man over women, which transcends different economic systems, eras, regions and class”. It has also been linked to the creation of societies that are less respectful of women's rights and potential, by which resources and the political economy are skewed towards males, who own the means of production, whereas women are exploited through the provision of cheap labour (Mojab and Gorman 2001; De Beauvoir 1989). The underlying value that has helped the ideology to survive for centuries finds locus on the idea that patriarchy is constructed, sustained and reproduced through social institutions and structures, which condone power imbalances 
and hierarchical power relations.

Coetzee (2001) concurs with the aforementioned views and posits that patriarchy thrives on the perpetuation of power imbalances between the sexes. The falsehood fuels an essentialism ideal that entitles them to a position of power over women. Patriarchy conceptualises women as inferior, intellectually and physically. Contrary accounts and research have disapproved the falsehoods (Mead 1935). Over time, the falsehoods have led to internalisation by a majority of women who have ended up accepting the status quo created and fuelled through gender stereotypes. Owing to this observation, Coetzee concludes that South Africans in general and the educational landscape in particular have not changed substantially. He attributes his claim to the idea that the patriarchal hegemony continues to thrive and exacerbate discrimination between the sexes (Coetzee 2001).

Race, patriarchy, and gender were the dominant ideologies behind the setting up of industrial and reformist institutions for the white destitute and deviant in the early 1900s in South Africa. Zulu (1998) also noted that the heightening of women's disempowerment happened through oppression and violence within social institutions and social structures. Structurally speaking, without a doubt, South Africa is still predominantly patriarchal in its social, economic and political undertakings and settings (Coetzee 2001).

The CGE (1998) and Coetzee (2001) argue that patriarchy was a common feature within both black and white communities, a fully-fledged ideology that was deep-rooted in Afro- and Eurocentric mythologies. It brutalised men whilst neutralising women across racial lines. Furthermore, a statement on the "Emancipation of Women in South Africa” issued by the ANC National Executive Committee, 2 May 1990, reinforced the notion that gender oppression is partially based on material endowments that are in the hands of men. Gender oppression is also exacerbated and expressed through deep-rooted structures of domination, socio-cultural practices, attitudes and traditions (Coetzee 2001). CGE (1998) further concluded that women were the most neglected and marginalised group of citizens in South Africa. In lieu of the sentiments expressed by Coetzee (2001), we can conclude that white and black men find it acceptable to talk about race rather than support gender issues that could jeopardise their institutional privilege. Any attempts to dispute or even question the supreme power of men is seen as going against the establishment's ideals and traditions as demonstrated in the quote below (CGE 1998).

“... thus to challenge patriarchy, to dispute the idea that it is men who should be dominant figures in the family and society, is to be seen not as fighting against the male privilege, but as attempting to destroy African tradition, or to subvert Afrikaner ideals or undermine civilised and deemed British values .... Patriarchy brutalises men and neutralises women across the colour line.” (CGE 1998, 10). 
Rifkin (1980) maintains that instead of the current laws challenging gender inequality, they concretise male domination. Likewise, the emergence of capitalism did not transcend the patriarchal or cultural exclusions of earlier civilizations. It excluded women from the public gaze of monetary exchange by relegating them to the private space of home and family (bride price, polygamy, child marriages and sex slaves). This was a reassertion of patriarchal and cultural hegemonies by supremacists, which objectified, commodified and essentialized women. Fraser (in Mills 2003, 215) argues that the gendered division of labour defined and reproduced men as independent and possessive individuals with rights. In contrast, women were defined and reproduced as dependent and defective, not possessive individuals with rights. Further, Fraser notes that regarding women's labour as inferior is detrimental. As such, they end up in private spaces; relegated to housekeeping chores, constant surveillance, and charity. This thinking has led to the institutionalisation and normalisation of male domination both in private and public spaces (Mills 2004).

\section{THE TRAJECTORY AND CONTEXT OF PAST TRENDS OF GENDER INEQUALITIES IN SOUTH AFRICAN EDUCATION}

During the apartheid era, the fostering of gender inequality in education was through the formal and informal curricula. It reinforced and reproduced the dominant hegemonic views of stereotypical masculinity and femininity (Marshall 2000). Labode (1993) and Msimang (2001) contend that the exclusionary nature of missionary education contributed to the perpetuation of patriarchal ideology. The aims of the colonial and missionary education were to promote domesticity and subservience and thus maintain social order and cohesion amongst the colonist communities. The system was to produce good Christian wives and mothers, according to Labode (1993) and Adeyemi and Adeyinka (2003). The training of "native” would enable them to take up leadership and entrepreneurial roles through training in farming, fighting, blacksmithing, masonry, and hunting. On the other hand, the "native" girls trained to become good wives and home keepers by learning sewing and housekeeping skills and religious studies with a bit of reading and writing. This kind of curriculum symbolically used femininity and masculinity in preparing girls and boys for their gender roles while excluding them from participating meaningfully in prominent societal activities (such as denying women adequate participation in politics, decision-making processes, the economy and nation building) (Murdock 1949; Parsons 1954; Bowlby 1969; Report of the Gender Equity Task Team 1997).

In addition, Verwoerd's 1954 speech (in Rose and Tunmer 1975, 265) instilled the gender stereotype of nurturance and caring: 
"Since a woman is by nature so much better fitted for handling young children and as the great majority of Bantu pupils are to be found in the lower classes of the primary school, it follows there should be far more female than male teachers in the service. The Department will ... declare the posts of assistants in lower and, perhaps to a certain extent in higher primary schools, to be female teachers' posts .... This measure in the course of time will bring about a considerable saving of funds, which can be devoted to another purpose, namely, to admit more children to school." (Rose and Tunmer 1975, 265).

The segregated and gendered nature of education under the apartheid regime substantially submerged black women's position in society. The few women, who managed to rise above their patriarchal disadvantage to venture into education, received inferior education aimed at cementing their roles as nurturers and home keepers. Molteno (1984) argues that Bantu Education syllabi did not prepare black women to hold any prestigious positions in society. It entrenched salient segregation, gendered roles, and acceptance of the status quo, with subordinate positions for blacks and superior ones for whites. They were taught basic communication skills and basic mathematics meant for semi-skilled work. Emphasis was on values such as honesty, cleanliness, punctuality, respect, and courtesy, all-important in serving the master. The curriculum further stressed nuanced and embodied states such as obedience, communal loyalty, ethnic and national diversity, acceptance of allocated social roles, piety and identification with rural culture (separation). This arrangement alienated women and heightened inequalities in all spheres of their lives (Lempert 2007; Lemmer 1993; Organization for Economic Co-operation and Development - OECD 2008).

As far as higher education is concerned, the black women's trajectory in accessing and participating in higher education was restricted and minimal. The exclusion depicted the intricate intersections that were systemic and ideological in nature. The CGE (1998); Badat (2009); Marshall (2000) and Jansen (2003) concur that women's marginalisation is a product of a conflation between perennial constraints of racism, patriarchy and social class. Badat (2009) observes that, black women's representation in higher education in the 1960s and 1970s was marginal. Thus, during the 1960s, women constituted 13.3 per cent (502) of the total black students’ enrolment. In 1970 black women enrolment climaxed at 18.9 per cent (1 580), and, in 1975 the recorded number stood at 21.6 per cent (3 928). The conclusion that can be drawn from this narrative is that, even the native universities espoused patriarchal tendencies (CGE 2000), they were monopolised by black males up until 1975 (Herman 1997). Further examples of cases of gender marginalisation are in the courses they studied. Thus, many women were concentrated in fields predominantly labelled as "feminine". They symbolise the problematic gendered traditional roles of nurturing and caring that are associated with mothers. Examples 
of such courses included nursing, secretarial work and paramedic employment, with the exception of teaching which had slightly more women than men in the same period. Courses such as Engineering, Agriculture, Computer Science, Architecture, and Law had very few black female enrolments (Badat 2009; Martineau 1997).

Furthermore, it was deliberate state policy to place female teachers in lower primary schools and male teachers in higher primary and secondary schools, based on a belief and assumption that the learners in lower primary still required care and therefore the female teachers would play a double role of mother and instructor (Molteno 1984; Rose and Tunmer 1975). Evans (1990) and Badat (2004) contend that it was part of the broader apartheid strategy to reproduce through teaching and research, white and male privilege, and black and female subordination. As such, the ramifications of this strategy still cuts across many disciplines to date. Currently, higher education is still grappling with the apartheid legacy as white males still hold prestigious positions in institutions of higher learning and research, knowledge production, and access to certain courses, and dominate postgraduate studies (DoE 1997).

Mosetse (1998); Hill and St Rose (2010) and Mutekwe et al. (2011) explicate that girls and women aspire to take up jobs that are considered suitable for females. According to Mosetse, the hidden curriculum has been responsible for such conditioning in many of the female students. Furthermore, Lemmer (1993) blames gender differentiation as far as subject and curriculum choice is concerned on the classification of subjects as being masculine or feminine. Science, Mathematics, Engineering, and Technology subjects and courses represent masculinity because they are "perceived as complex". Arts, Languages, Social Science and Hospitality-related subjects are "the preserve of women". The depiction of women in textbooks and school structures is also to blame for entrenching the inferior positions allocated to them. In most cases, society and social institutions assign "important or meaningful roles that require serious work and intellectual capability and capacity”. Roles such as being a granny, a mother, a queen, a princess or a witch feed into the narrative that women are domesticated, and, ought not to be taken seriously outside their homes (Hill and St Rose 2010; Mutekwe et al. 2011). Additionally, Schoeman (1998) argue that the diminishing of women's worth is due to the essentialized portrayal that is associated with their bodies and seen as the glamorous possessions of men. All these factors, positive or negative, have a bearing on how girls and women see themselves in institutions of learning and the career choices that they deem appropriate for themselves.

Hill and St Rose (2010) argue that performance and motivation of girls in mathematics depends on environmental factors. Teachers and parents develop bad attitudes about the subject 
if their ability is in doubt. Those who are encouraged become confident and excel. By persistently using stereotypes, such as boys are better than girls in maths and science, does lower girls' aspirations in these fields. At the same time, stereotypes lead to lower selfassessment for girls in maths and science subjects. Additionally, combining low self-esteem and self-fulfilling prophesies contribute to low enrolment in STEM subjects (Hill and St Rose 2010). Having noted the above factors that deter women from participating in STEM subjects and courses, I argue that knowledge and learning are inseparable from daily experiences. This is contrary to the "straitjacket of the masculine paradigm" that ignores the role non-academic factors play in the learning experience of women (Farganis 1994, 40). The point I am making here is in relation to the interconnectedness between the formal and informal aspects of women's lives that contribute to their overall trajectory in higher education.

Finally, Hill and St Rose (2010) maintain that the issue of gender inequity and inequality in higher education is complex. The socialisation at home, which at times makes women believe that certain domains are out of reach for them, is partly responsible for gender skewing. The curriculum and the interactions that take place in the lower tiers of education, reinforces a similar message. By the time these women get to institutions of higher learning, the damage is irreversible. I therefore suggest that education in general should take cognisance of these factors, identify, mentor, and groom future women scientists and engineers.

\section{POST-STRUCTURALISM AND GENDER INEQUITY IN THE WHITE PAPER (DoE 1997)}

Post-structuralism claims that understanding language usage is important in determining accuracy, clarity, and meaning in concepts and debates. The discussion on language provides a useful foundation for assessing the selection of the kind of language policy documents (textually). It is also imperative to note that policy documents are not simplistic texts, they are complex, and they are loaded with meaning whose interpretation is subjective (Derrida 1976; Ball 2006). Thus, language shapes the way they are articulated and vocalised. It moves the focus on policies from mere texts to forces that reflect social struggles of meaning, acceptance, and rejection and negotiated settlements. It is upon this basis that I argue for clarity of meaning for concepts such as gender, equity, equality and access. This article has adapted a social construction meaning of gender that sees gender beyond the biological factors that are associated with sex. Gender identity is multifaceted, arising from social relations, historical factors, and cultural practices that use masculinity and femininity to determine gender roles (Oakley 1985). 
I concur with the theorisation of social construction theories of gender and feminisms in illustrating that gender subjectivisms are unique, particular and contextual. Gender intersects with other lived states in ways that influence how gender is lived and experienced on a daily basis. As a result, thereof, a post-structural lens envisages a particular way of portraying and conceptualising gender in higher education policies. The point is that, womanhood is diverse; hence, this calls for the recognition of the heterogeneity within their various states. Such a position assumes that reality is fissured, subjective and socially constructed - plurality of existence (Miller 1999; Sen 1980).

Besides, a somewhat narrow conceptualisation of gender that looks at women as a coherent group of people does not encapsulate the particular and specific circumstances of social justice (Young 1990; Nussbaum 1999; Rawls 2009; Butler 1988). I argue that not addressing needs of students holistically - of race, poverty, sexism, sexual harassment, epistemological access, language and social class (male and female) - subverts the promise of equity in the reform agenda. Apart from the abolishment of unjust discrimination, The White Paper (DoE 1997) envisaged the assessment of transformation attained in higher education through an empowerment continuum. Thus, among other curtailments to accessing higher education, the White Paper identified financial empowerment as a key factor in accelerating equitable access to opportunities by individuals and institutions.

“... transformation involves not only abolishing all existing forms of unjust differentiation, but also measures of empowerment, including financial support, to bring about equal opportunity for individuals and institutions.” (DoE 1997, White Paper 1.18).

Weedon (1997) postulates that meanings do not exist prior to events, experiences or discourses. Meanings are articulated, and they penetrate in discourses of power, subjectivity, culture, historical contexts, and language. Alternatively, the construction of people's sense of self (people's subjectivity) happens through involvement and interaction with overarching and dominant discourses in society (Weedon 1997, 20). In this case, post-structuralism brings to life debates about social justice by questioning and scrutinising practices and allocated meanings of constructs such as gender, equity, equality in redress policies and institutions that purport to be democratic and in support of social justice. Ultimately, people have to be alert to the intended conceptual usage and the meaning in those concepts. As earlier iterated, the existence of an intricate relationship between the macro and micro institutions cannot be ignored (Mills 2003). In this regard, post-structuralism also makes explicit the role social institutions and contexts play in reproducing overt and covert hierarchical power relations used 
in defining and determining social roles and positioning of women in societies. As for South African higher education, black female students in higher education are currently embroiled in debates that are questioning the very essence of transformation. In essence, a majority of them, who are deserving and academically able, do not have access to opportunities equitably. This situation impedes their dreams of accessing higher education and, succeeding in the institutions that have not transformed fully (Buhlungu 2015). Consequently, Ramagosh (in Chisholm and September 2005) contends that; no matter how well the government's intentions are in wanting to redress the past gender imbalances, "the face of the vehicles we use to address these is masculine and it wears a traditional and cultural mask” (Ibid., 135).

I also argue that the measurement of the attainment of equity is also problematic. Section 2.24 of the White Paper (DoE 1997) indicates the possibility of achieving gender and race equity through massification (a massive increase of student enrolment). Further, the policy states that expansion of access would improve representation of blacks, and women in particular, in all higher education programmes (which they had been excluded from), including SET and postgraduate studies. In the beginning, this looked promising and was a laudable move under the prevailing circumstances (a segregated and differentiated landscape along sexism, racism, classism, ethnicity and geographical positioning planes). Nonetheless, the support for the move is slowly waning due to sustainability challenges. To say the least, an increase in the number of black people and women in university lecture halls does not amount to greater equity and equality. Arguably, tackling the mundane realities - (that emanate from social class stratification, power imbalances, sexism, racism, and articulation gap) is the crux of the transformation project (Unterhalter 2007). Current literature shows that the metaphorical nut has not been cracked, as there are high dropout rates, low throughput and low enrolments in postgraduate studies amongst black students in general (CHE 2010; Badat 2009). This revelation is testament to the struggles that the previously marginalised students encounter continuously in institutions of higher learning. The disequilibrium between undergraduate and postgraduate enrolments poses serious challenges for higher education and South Africa at large according to the Minister for Higher Education, Dr. Blade Nzimande, quoted in the Mail \& Guardian as saying:

"The average age of academics at South African universities is about 55 years, which means if we don't do something drastic the implications are that we will run short of academics. In some respects, we are experiencing that already.” (Mail \& Guardian 15 October 2014).

The dichotomy of limitations posed by financial lack and academic rigor are partially to blame 
for this conundrum. However, Robus and Macleod (2006) argue that racism is deeply entrenched in South African higher education institutional structures and practices. The "failure" of the current policies to achieve their objectives sufficiently is attributable to the conceptualisation and the nature of policy processes. Policies and legislation as instruments of redress address themselves to global and macro aspects of the problem. Often, the tragedy of the macro aspects taking precedence over the micro aspects of social justice cannot be underestimated (Young 1990; Fraser 2008; Rawls 1971). While supporting the need to rethink the micro aspects, Robus and Macleod $(2006,478)$ note that, "these macro processes are intricately imbricated in people's everyday talk and practices, which maintain, reproduce, or undermine institutional racism in complex ways”.

Knowledge production and dissemination is one of the key functions of higher education. However, post-structuralism makes a fundamental point regarding lapsing into structuralism's conceptualisation of knowledge as homogeneous, singular, and unified (Foucault 1984). Foucault (1984) observes that post-structuralism's vantage point provides a vanguard for being critical about the metaphysical universalisation of the concepts of power, knowledge, truth, identity, subjectivity, and causality. Objective realities do not amount to knowledge. Arguably, knowledge cannot be divorced from the communities it serves and human interest (Foucault 1984). Foucauldian account of knowledge and truth relocates the gaze to production of knowledge and truth from social structures to social relations. Thus, he describes truth as being produced from social relations, but on the other hand political power is, "the ground upon which the subject, the domains of knowledge, and the relations with truth is formed” $(1984,15)$.

Post-structuralists also abrogate claims advanced by foundation theories that allege that “subjectivity”, “subject” and “object” are contradicting states. In refuting these claims, poststructuralism argues that subjectivism and objectification are interlinked and inseparable. Foucault (2002) in his work, Order of things maintains that individuals occupy subject and object positions simultaneously. Human beings are subject to and subject of questions of truth and falsehood and the object of truth. Furthermore, post-structuralism contests the essentialist view of the existence of a rational, fixed and coherent individual who is unaffected by the whims of culture and history. Essentially, post-structuralism destabilises the universal subject created through structuralism and humanism episteme. It is the thesis of post-structuralism that, rather than viewing human beings as universal, they should be understood as beings that occupy different subject positions, which lead to multiple identities. Cultural practices mediate and rationalise particularised discourses that operate within competing discursive contexts such as gender, class, age, sexism, and ethnicity (Baxter 2003; Butler 1988). These contexts in turn 
affect the manner in which they experience access in higher education.

Consequently, Weedon (1997) and Weiner (1994) maintain that post-structural theories expose people to conflicting frameworks of knowledge that replicate the historical and contextual demeanour of a society. A post-structural gaze "uses things that are considered personal and private to explain the experiences and positions of individuals/subjects in public and shared positioning”. In the case of South African higher education, the student composition embodies fractured identities, the identities inform their experiences in post-1994 higher education. The experiences are group related (race) and personal. The CGE (1998) points out the inaccuracy of one race group speaking on behalf of the other. The struggles are not the same and there is a danger in misrepresenting the experiences of the other in important debates. The excerpt (Hassim and Walker 1993) below supports the commission’s claims:

"Yes, I am middle class because I have had access to education, but experientially I am a member of an underclass, and that is something that I feel I need to articulate. It cannot be articulated for me ... white women are championing the struggles of black women. It is unacceptable. It is simply unacceptable, because as long as you continue to be the vanguard of the black women's struggle, she remains silent. ... You publicise, you popularise, but to democratise knowledge, you actually have to let her speak for herself .... Academic rigour is not an excuse for excluding the majority of women in South Africa ... I need to actually be a researcher, no longer a fieldworker.” (Participant at the Conference on Women and Gender in Southern Africa). (Hassim and Walker 1993, 523).

South African higher education policies aspire towards equipping prospective students with relevant and "unbiased” knowledge regardless of their race, socio-economic backgrounds or gender. Unity in diversity is a celebratory statement in post-apartheid South Africa. Section 1.3 of the White Paper (DoE 1997) recognises the important role higher education is supposed to play in the rebuilding and reconstructing of society. Similarly, through an academic scholarship and academic inquiries, higher education becomes a vehicle of fast tracking students' intellectual development; acquisition of valuable knowledge; dissemination and share in the creation of knowledge. The vision espoused in the White Paper is not clear, especially for a majority of the previously disadvantaged students who encounter a plethora of impediments (language, epistemological access, socio-economic, sexism and racism) on their journey to academic excellence and freedom in the academy. Notably, more often than not, the journeys come to an abrupt end due to high dropout rates, attrition, repetition, and low throughput. In addition, in congruencies still exist in the areas of claims to knowing, knowledge and publication, which are still largely in the hands of white middle class men, a grey area for black women in particular (Morrow 1994; CHE 2009; Badat 2009; Unterhalter 2007).

Cross (2004) stipulates that, the reform trajectory in South African higher education has 
created new challenges for institutions of higher learning. Never before had institutions of higher learning been infiltrated by a diverse group of students (race, religion, social class, culture and linguistic) that was witnessed post-1994. The influx has left higher education grappling with reconvening and reconstituting appropriate meanings and strategies that would deal with the elements of diversity, diversification, and diversity issues. As a matter of social justice and equity, Cross (2004) highlights the need to converge on issues relating to the convolution of knowledge, pedagogical practices, epistemological access and diversity.

On the relationship between power and knowledge, Foucault (1984) abstracts that, power is relational (certain people exercise power over others) and that those who are in a position of subordination do actually resist the domination. Foucault states that power is not only coercive and wielded like a weapon by the people in capital and in state; but power transcends the macro social level; it operates within multiple sites at local levels. Likewise, power is not only repressive or wielded by one social class or institution over the subordinate classes; power flows in multiple directions. Thus, even within the subordinate class, different levels of power imbalances are experienced. Foucault contends that power is not absolute and that sites of power and knowledge are rife with production, resistance and contestation of the "truth" (Foucault 1984). Foucault's theorisation of power exposes it as understated and yet insidious.

Van Dijk (2014) agrees with Foucault and further maintains that the dominant group can influence and at the same time curtail freedom of the underprivileged people in various ways. Power is facilitated through force (coercion), recourse, manipulation or persuasion. As to how power and knowledge conflate, Van Dijk (2014, 302) establishes that people can be managed through everyday routine, subtle talk and text that seems natural and acceptable to them and yet the real meaning is hidden and inaccessible due to the complexity of the purportedly natural and accessible texts and talk. Foucault (1984) demonstrates that acceptance of social inequality and inequity is part of incorporating discourse into people's sense of self and subjectivity. Institutionalisation of disciplinary power discourses of truth, gender, sexuality, racism, subordination and dominance are "taken for granted”, “consolidated” and "normalised”.

During the colonial and apartheid days various people occupying different social sites and positions institutionalised power imbalances in order to sustain the hegemonic and ideological positions of their various regimes in what Foucault calls disciplinary power (hospitals, politics, economy, religion, schools or prisons) (Foucault 1984). Conversely, post-structuralism theories realise the difficulty of extricating power from human life and that absolute power corrupts absolutely. They reckon that those in power never give up their privileges voluntarily and hence, those operating from the periphery and margins of power may have to be persuasive and more 
creative if they have to share in power arrangements. I therefore contend that any evaluation of policy ought to look beyond the physical text that arrives at institutions and concentrate on the complexities in policy texts. They are loaded with meaning, and they are implicated in power struggles and relations. Ball (2006) enunciates that, often people receive new policies with a lot of scepticism. This is due to the fear of the accompanying effects that are restructuring, redistributing and disrupting of power relations and arrangements. This destabilises the existing power relations, which might stir a fierce rebellion from those who may want to retain the status quo.

\section{CONCLUDING REMARKS}

Arguably, previous abstractions that indicated that South African women suffered substantially in the past are correct. The reform agenda was necessary to address gender gaps in relation to black women's access to higher education. Notwithstanding all the gains, black women in higher education still grapple with a myriad of disadvantaging situations. The White Paper (DoE 1997) conceived a higher education landscape that will be replete with equal statuses for all regardless of gender, race, social status or creed. However, in spite of the promises, race equity has overshadowed gender equity (Akala 2016; Hassim 1991; Martineau 1997). Attempts to dislodge gender inequalities and inequities have not been very successful because the approach has tended to homogenous women's circumstances and experiences. Finally, it is my proposition that although equality and equity convolute, the two notions should be viewed separately, each one with clear goals. Preferably, I suggest, in addition to existing interventions, a broader and multifaceted approach that reflects the divergent states embodied by the marginalised women in higher education spaces (equity paradigm) to be considered as a mechanism of obliterating gender inequities and inequalities.

\section{REFERENCE LIST}

Adeyemi, M. and A. Adeyinka. 2003. The principles and content of African traditional education. Educational Philosophy and Theory 35(4): 425-440.

Akala, B. 2016. Gender equity tensions in higher education: A critique of post-apartheid gender equity policy. Doctoral dissertation.

Akala, B. and J. J. Divala. 2016. Gender equity tensions in South Africa's post-apartheid higher education: In defence of differentiation. South African Journal of Higher Education 30(1): 1-16.

Badat, S. 2004. Transforming South African higher education, 1990-2003: Goals, policy initiatives and critical challenges and issues. In National policy and regional response in South African higher Education, ed. N. Cloete, P. Pillay, S. Badat, T. Moja, 1-50. James Curry (Oxford), David Phillip (C.T.).

Badat, S. 2009.Theorising institutional change: Post 1994 South African Higher education. Studies in Higher Education 3(4): 455-467. 
Ball, S. J. 2006. Education policy and social class. Routledge

Baxter, J. 2003. Positioning gender in discourse: A feminist methodology. Springer.

Bowlby, J. 1969. Attachment and loss: Attachment; John Bowlby. Basic Books.

Buhlungu, S. 2015. Brazen "trickery” in transformation. Mail and Guardian, March, 6.

Butler, J. 1988. Performative acts and gender constitution: An essay in phenomenology and feminist theory. Theatre Journal 40(4): 519-531.

Butler, J. 1990. Gender trouble, feminist theory, and psychoanalytic discourse: In Feminism/ Postmodernism, ed. L. J. Nicholson. London: Routledge

CGE see Commission on Gender Equality.

CHE see Council on Higher Education.

Chisholm, L. and J. September. (Eds.). 2005. Gender Equity in South African Education 1994-2004: Perspectives from Research, Government and Unions; Conference Proceedings. HRSC Press, Cape Town: South Africa.

Coetzee, D. 2001. South African education and the ideology of patriarchy. South African Journal of Education 21(4): 300-304.

Comaroff, J. 2013. Body of power, spirit of resistance: The culture and history of a South African people. University of Chicago Press.

Commission on Gender Equality. 1998. Annual report of the Commission on Gender Equality. Pretoria.

Commission on Gender Equality. 2000. Promotion of Gender Equality and Prevention of Unfair Treatment Act No. 4. Pretoria: Government Printer

Council on Higher Education. 2009. The State of Higher Education. Higher Education. Monitor No. 8. A report of the CHE Advise and Monitoring Directorate. Pretoria.

Council on Higher Education. 2010. Access and throughput in South African higher education: Three case studies. Higher education Monitor No. 9. A report of the CHE Advise and Monitoring Directorate. Pretoria.

Council on Higher Education. 2013. A proposal for undergraduate curriculum reform in South Africa: The case for a flexible curriculum structure. Pretoria.

Cross, M. 2004. Institutionalising campus diversity in South African higher education: Review of diversity scholarship and diversity education. Higher education 47(4): 387-410.

De Beauvoir, S. 1989. The second sex. Translated and edited by H. M. Parshley. New York: Vantage Books

De la Rey, C. and A. Kottler. 1999. Societal transformation: Gender, feminism and psychology in South Africa. Feminism \& Psychology 9(2): 119-126.

Department of Education. 1997. White Paper A programme for the transformation of higher Education. Pretoria.

Department of Education and Training. 2012. Draft Green Paper (Discussion Document). Pretoria.

Derrida, J. 1976. Of grammatology. Translated by Gayatri Chakravorty Spivak, Baltimore.

DET see Department of Education and Training.

DoE see Department of Education.

Evans, I. 1990. The racial question and intellectual production in South Africa. Perspectives in Education 11(2): 21-35.

Farganis, S. 1994. Situating feminism: From thought to action (Vol. 2). Sage publications

Fraser, N. 2005. Reframing justice. Uitgeverij Van Gorcum.

Fraser, N. 2008. Adding insult to injury: Nancy Fraser debates her critics, ed. K. Olson. London: Verso.

Foucault, M. 1984. The ethics of the concern for the self as a practice of freedom. In Michel Foucault: 
Ethics, subjectivity, and truth, ed. Paul Rabinow, 281-301.

Foucault, M. 2002. The order of things: Archaeology of the human sciences. Psychology Press.

Hassim, S. 1991. Gender, social location and feminist politics in South Africa. Transformation 15: 6582.

Hassim, S. and C. Walker. 1993. Women's studies and the women's movement in South Africa: Defining a relationship. Women's Studies Int. Forum 16(5): 523-534.

Herman, H. 1995. School-leaving examinations, selection and equity in higher education in South Africa. Comparative Education 31(2).

Hill, C., C. Christianne and A. St Rose. 2010. Why so few? Women in Science, Technology, Engineering, and Mathematics. American Association of University Women. 1111 Sixteenth Street NW: Washington, DC

Jansen, J. 2003. The state of higher education in South Africa: From massification to mergers. State of the nation. South Africa, 290-311.

Labode, M. 1993. From heathen kraal to Christian home: Anglican mission education and African Christian girls, 1850-1900. Women and missions: Past and present, 126-44.

Lemmer, E. 1993. Gender issues in education. In Critical issues in modern education, ed. E. I. Dekker and E. M. Lemmer. Johannesburg: Heinemann.

Lempert, L. B. 2007. Cross-race, cross-culture, cross-national, cross-class, but same-gender: Musings on research in South Africa. NWSA Journal 19(2): 79-103.

Lorde, A. 1984. The master's tools will never dismantle the master's house. In Sister outsider, ed. A. Lorde, 110-113. Tramansburg, NY: The Crossing Press.

MacKinnon, C. 1987. Feminism unmodified: Discourses on life and law. Cambridge, MA: Harvard University Press.

MacKinnon, C. 1993-4. Crimes of war, crimes of peace. UCLA Women's Law Journal (4).

Mail and Guardian. 2014. Government sets aside 169 million for academic staff, October 15. https://mg.co.za/ .../2014-10-15-government-sets-aside-r169-million-for-academic-staf

Martineau, R. 1997. Women and education in South Africa: Factors influencing women's educational progress and their entry into traditionally male-dominated fields. Journal of Negro Education: 383-395.

Marshall, C. 2000. Policy discourse analysis: Negotiating gender equity. Journal of Education policy 15(2): 125-156.

Mead, M. 1935. Sex and temperament in three primitive societies (Vol. 370). New York: Morrow.

Meintjies, S. 1996. The women's struggle for equality during South Africa's transition to democracy. Journal of Transformation (30).

Miller, D. 1999. Principles of social justice. The presidents and fellows of Harvard College, USA.

Mills, S. 1997. Discourse. London and New York. Routledge.

Mills, M. B. 2003. Gender and inequality in the global labor force. Annual Review of Anthropology 32(1): 41-62.

Mojab, S. and R. Gorman. 2001. The struggle over lifelong learning: A Marxist-Feminist analysis.

Molteno, F. 1984. The historical foundations of the schooling of black South Africans. Apartheid and education: The education of black South Africans, 45: 107.

Morrow, W.1994. Teacher education in plural societies. Entitlement and achievement in education. studies in philosophy and education. In International Review, ed. M. Craft, 13: 95-107.

Mosetse, P. 1998. Gender stereotypes as a structure of domination in South African education. Unpublished MEd dissertation UOFS: Bloemfontein.

Murdock, G.1949. Social structure. New York: Macmillan, 
Mutekwe, E., M. Modiba and C. Maphosa. 2011. Factors affecting female students' career choices and aspirations: A Zimbabwean example. Journal of Social Sciences 29(2): 133-141.

Msimang, S. 2001. Affirmative action in the new South Africa: The politics of representation, law and equity. Women in Action No. 2.

Nussbaum, M. 1999. Women and equality: The capabilities approach. International Labour Review 138(3): 227-245.

Nussbaum, M. C. 2009. Frontiers of justice: Disability, nationality, species membership. Harvard University Press.

Oakley, A. 1985. Sex, gender and society rev. Aldershot: Gower.

OECD see Organisation for Economic Co-operation and Development.

Organisation for Economic Co-operation and Development. 2008. Reviews of national policies for education: South Africa: OECD Publishing.

Parsons, T. 1954. Essays in sociological theory. Revised Edition. Ill: Free Press.

Rawls, J. 1971. A theory of justice. Oxford: Clarendon Press.

Rawls, J. 2009. A theory of justice. Harvard University press.

Rifkin, J. 1980. Toward a theory of law and patriarchy. Harvard Women's LJ 3: 83.

Robus, D. and C. Macleod. 2006. White excellence and black failure: The reproduction of racialised higher education in everyday talk. South African Journal of Psychology 36(3): 463-480.

Rose, B. and R. Tunmer. 1975. Documents in South African education. Donker.

Schoeman, M. 1998. An exploration of the link between security and development. Security, Development and Gender in Africa, ISS Monograph 27: 12-13.

Seidman, G. W. 2003. Institutional dilemmas: Representation versus mobilization in the South African Gender Commission. Feminist Studies 29(3): 541-563.

Sen, A. 1980. Equality of what? In The Tanner lectures on human values, ed. S. McMurrin. Salt Lake City: Utah.

Tiger, L. and R. Fox. 1972. The imperial animal. London: Secker and Warburg.

Unterhalter, E. 2007. Gender, schooling and global social justice. London: Taylor Francis Routledge.

Van Dijk, T. 2014. Discourse and knowledge: A socio-cognitive approach. Cambridge University Press.

Walker, C. 1990. Women and gender in Southern Africa to 1945. New Africa Books.

Walker, M. 2005. Rainbow nation or new racism? Theorizing race and identity formation in South African higher education. Race Ethnicity and Education 8(2): 129-146.

Weedon, C. 1997. Feminist practice and poststructuralist theory. $2^{\text {nd }}$ Edition. Oxford: Blackwell.

Weiner, G. 1994. Feminisms in education: An Introduction. Buckingham: Open University Press.

Zulu, L. 1998. Role of women in the reconstruction and development of the new democratic South Africa. Feminist Studies 24(1): 147-157.

Young, I. M. 1990. Justice and the politics of difference. Princeton, NJ: Princeton University Press. 